\title{
Solubility product challenge
}

\author{
Anna Maria Michałowska-Kaczmarczyk • \\ Tadeusz Michałowski
}

(C) Springer-Verlag Berlin Heidelberg 2015

We would like to invite you to participate in the Analytical Challenge, a series of puzzles to entertain and challenge our readers. This special feature of "Analytical and Bioanalytical Chemistry" has established itself as a truly unique quiz series, with a new scientific puzzle published every other month. Readers can access the complete collection of published problems with their solutions on the ABC homepage at http://www. springer.com/abc. Test your knowledge and tease your wits in diverse areas of analytical and bioanalytical chemistry by viewing this collection.

In the present challenge, solubility is the topic. And please note that there is a prize to be won (a Springer book of your choice up to a value of $(100)$. Please read on...

\section{Introduction}

Determination of the solubility of different substances is an important area of physicochemical study. To this end, IUPAC Subcommittee on Solubility and Equilibrium Data regularly publishes solubility data which now amounts to one hundred volumes [1]. The solubility product, $K_{\mathrm{sp}}$, is a special type of equilibrium constant related to a heterogeneous system containing a sparingly soluble solid phase and a solution saturated towards this phase (precipitate). Commonly, the solubility product for a solid

A. M. Michałowska-Kaczmarczyk

Department of Oncology, The University Hospital in Cracow,

31-501 Cracow, Poland

T. Michałowski $(\bowtie)$

Faculty of Engineering and Chemical Technology,

Technical University of Cracow, 31-155 Cracow, Poland

e-mail: michalot@o2.pl phase $\mathbf{M e}_{n} \mathbf{L}_{\boldsymbol{u}}$ is the equilibrium constant of a hypothetical dissociation reaction into constituent ions:

$\mathbf{M e}_{n} \mathbf{L}_{u}=n \mathrm{Me}^{u+}+u \mathrm{~L}^{n-}$

Equation 1 is exemplified reactions.

$\mathrm{Zn}(\mathbf{O H})_{\mathbf{2}}=\mathrm{Zn}^{2+}+2 \mathrm{OH}^{-}$

Equations 1 and 2 are characterized by the corresponding solubility products:

$K_{\text {sp }}=\left[\mathrm{Me}^{u+}\right]^{n}\left[\mathrm{~L}^{n-}\right]^{u}\left(\right.$ for the precipitate $\left.\mathbf{M e}_{\boldsymbol{n}} \mathbf{L}_{\boldsymbol{u}}\right)$

$K_{\mathrm{sp}}=\left[\mathrm{Zn}^{2+}\right]\left[\mathrm{OH}^{-}\right]^{2}\left(\right.$ for the precipitate $\left.\mathbf{Z n}(\mathbf{O H})_{\mathbf{2}}\right)$

It is rather common to find in the literature (e.g. Refs. [2, 3]) "ready to use" formulas to calculate the solubility, $s^{*}$, of pure substances $\mathbf{M e}_{n} \mathbf{L}_{\boldsymbol{u}}$ (salts, hydroxides) when introduced in excess into pure water. It is also assumed that $\left[\mathrm{Me}^{u+}\right]=n \cdot s^{*}$ and $\left[\mathrm{L}^{n-}\right]=u \cdot s^{*}$. Then, from Eqs. 3 and 4, we have:

$s^{*}=\sqrt[n+u]{\frac{K_{\mathrm{sp}}}{n^{n} \cdot u^{u}}}$

$s^{*}=\sqrt[1+2]{\frac{K_{\mathrm{sp}}}{1^{1} \cdot 2^{2}}}=\sqrt[3]{\frac{K_{\mathrm{sp}}}{4}}$

In each particular case, it is tacitly assumed that the solution is saturated with respect to the solute. But this is not always true. In this challenge we will reveal that Eq. 5 and similar are flawed and can lead to incorrect solubility values. 


\section{Meet the challenge}

The occurrence of the chemical reactions in Eqs. 1 and 2 is fictitious, and the actual processes occurring are usually rather complex. In some systems, several solid phases can be formed, as exemplified by the dissolution of struvite $\left(\mathrm{MgNH}_{4} \mathrm{PO}_{4}\right)$ [4] or dolomite $\left(\mathrm{CaMg}\left(\mathrm{CO}_{3}\right)_{2}\right)$ [5]. For example, after the introduction of an excess of struvite into pure water, the equilibrium solid phase is not struvite, but $\mathbf{M g}_{3}\left(\mathbf{P O}_{4}\right)_{2}$; i.e., the reaction

$\mathbf{3 M g N H}_{4} \mathbf{P O}_{4}=\mathbf{M g}_{3}\left(\mathbf{P O}_{4}\right)_{2}+\mathrm{HPO}_{4}{ }^{2-}+2 \mathrm{NH}_{4}{ }^{+}+\mathrm{NH}_{3}$

occurs. Although this was observed experimentally long ago [6], the formula $s^{-}=\sqrt[3]{K_{\mathrm{sp}}}$, where $K_{\mathrm{sp}}=\left[\mathrm{Mg}^{2+}\right]\left[\mathrm{NH}_{4}{ }^{+}\right]\left[\mathrm{PO}_{4}{ }^{3-}\right]$, is still in use, e.g. in Ref. [7].

The example presented above reveals that the schematic problem solving of solubility can give inaccurate or false results. Correct solution of the problem is based on the application of equations for charge and concentration balances [8], along with a complete set of equations for the corresponding equilibrium constants. The solution of complex electrolytic systems frequently requires iterative calculations [4, 5], and in some simple cases one can apply the "zeroing procedure" using Excel. Naturally, the zeroing refers to searching of $\mathrm{pH}$ value where the equation for charge balance $\mathrm{z}(\mathrm{pH})=0$, is fulfilled. This procedure is illustrated here for calculating the solubility of $\mathbf{Z n}(\mathbf{O H})_{2}$ in water.

An excess of $\mathbf{Z n}(\mathbf{O H})_{2}$, when introduced into pure water, is a solid phase in equilibrium with the solution, where the (soluble) zinc species $\mathrm{Zn}^{2+}$ and $\mathrm{Zn}(\mathrm{OH})_{i}^{+2-i}$ are formed. Denoting $\left[\mathrm{Zn}^{2+}\right]\left[\mathrm{OH}^{-}\right]^{2}=K_{\mathrm{sp}} \quad\left(\mathrm{p} K_{\mathrm{sp}}=15.0\right)$, $\left[\mathrm{Zn}(\mathrm{OH})_{i}^{+2-i}\right]=K_{i}{ }^{\mathrm{OH}}\left[\mathrm{Zn}^{2+}\right][\mathrm{OH}]^{i}$, where $i=\{1,2,3,4\}$ and $\log K_{i}^{\mathrm{OH}}=\{4.4,11.3,13,14,14.66\}$, and $\left[\mathrm{H}^{+}\right]\left[\mathrm{OH}^{-}\right]=$ $K_{\mathrm{w}}\left(\mathrm{p} K_{\mathrm{w}}=14\right)$, we formulate the charge balance:

$\left[\mathrm{H}^{+}\right]-\left[\mathrm{OH}^{-}\right]+2\left[\mathrm{Zn}^{2+}\right]+\left[\mathrm{ZnOH}^{+}\right]-\left[\mathrm{Zn}(\mathrm{OH})_{3}{ }^{-}\right]-2\left[\mathrm{Zn}(\mathrm{OH})_{4}{ }^{2-}\right]=0$ which can be transformed into the following form:

$$
\begin{aligned}
\mathrm{z}= & \mathrm{z}(\mathrm{pH})=10^{-\mathrm{pH}}-10^{\mathrm{pH}-\mathrm{pK}_{\mathrm{W}}}+2 \cdot 10^{2 \mathrm{pK}_{\mathrm{W}}-\mathrm{pK} \mathrm{sp}_{\mathrm{pp}}-2 \mathrm{pH}}+10^{\operatorname{logK}_{1}{ }^{\mathrm{OH}}+\mathrm{pK}_{\mathrm{W}}-\mathrm{pK} \mathrm{Sp}_{\mathrm{sp}}-\mathrm{pH}} \\
& -10^{\log _{3}{ }^{\mathrm{OH}_{-}}-\mathrm{pK}_{\mathrm{sp}}-\mathrm{pK}_{\mathrm{W}}+\mathrm{pH}}-2 \cdot 10^{\log _{4}{ }^{\mathrm{OH}_{-}}-\mathrm{pK}_{\mathrm{sp}}-2 \mathrm{pK}_{\mathrm{W}}+2 \mathrm{pH}}=0
\end{aligned}
$$

Using Excel (see Table 1), we find that the function $z=z(\mathrm{pH})$ zeroes at $\mathrm{pH}=\mathrm{pH}_{0}=9.121$. Hence, $\mathrm{pH}_{0}$ is the $\mathrm{pH}$ of the solution in equilibrium with $\mathbf{Z n}(\mathbf{O H})_{2}$. On this basis, we calculate the solubility:

$$
\begin{aligned}
s & =\left[\mathrm{Zn}^{2+}\right]+\left[\mathrm{ZnOH}^{+}\right]+\left[\mathrm{Zn}(\mathrm{OH})_{2}\right]+\left[\mathrm{Zn}(\mathrm{OH})_{3}{ }^{-}\right]+\left[\mathrm{Zn}(\mathrm{OH})_{4}{ }^{2-}\right] \\
& =2.07 \times 10^{-4} \mathrm{~mol} \mathrm{~L}^{-1} .
\end{aligned}
$$

This value differs significantly from $s^{*}=\sqrt[3]{K_{\mathrm{sp}} / 4}=6.3 \times 10^{-6} \mathrm{~mol} \mathrm{~L}^{-1}$.

\section{The challenge}

Dimethylglyoxime (HL) is a weak monoprotic acid, first reported by Chugaev in 1905 [9]. It is used for gravimetric determination of nickel by precipitation of its dimethylglyoximate salt, $\mathbf{N i L}_{\mathbf{2}}$. In the solution obtained after introducing pure $\mathbf{N i L}_{2}$ into pure water are the soluble species: $\mathrm{HL}, \mathrm{L}^{-}, \mathrm{Ni}^{2+}, \mathrm{NiOH}^{+}$, and $\mathrm{NiL}_{2}$. This system is characterized by the following equilibrium constants [10]:

$$
\begin{aligned}
\mathrm{p} K_{\mathrm{a}, \mathrm{HL}} & =10.6 \text { for } K_{\mathrm{a}, \mathrm{HL}}=\left[\mathrm{H}^{+}\right]\left[\mathrm{L}^{-}\right] /[\mathrm{HL}] \\
\mathrm{p} K_{\mathrm{sp}} & =23.66 \text { for } K_{\mathrm{sp}}=\left[\mathrm{Ni}^{2+}\right]\left[\mathrm{L}^{-}\right]^{2} ; \\
\log K_{2 L} & =17.24 \text { for } K_{2 \mathrm{~L}}=\left[\mathrm{NiL}_{2}\right] /\left(\left[\mathrm{Ni}^{2+}\right]\left[\mathrm{L}^{-}\right]^{2}\right) ; \\
\log K_{1}{ }^{\mathrm{OH}} & =4.6 \text { for } K_{1}{ }^{\mathrm{OH}}=\left[\mathrm{NiOH}^{+}\right] /\left(\left[\mathrm{Ni}^{2+}\right]\left[\mathrm{OH}^{-}\right]\right) ; \\
\mathrm{p} K_{\mathrm{W}} & =14.0 \text { for } K_{\mathrm{W}}=\left[\mathrm{H}^{+}\right]\left[\mathrm{OH}^{-}\right] .
\end{aligned}
$$

\begin{tabular}{|c|c|c|c|c|c|c|c|}
\hline $\mathrm{pH}$ & {$\left[\mathrm{Zn}^{2+}\right]$} & {$\left[\mathrm{ZnOH}^{+}\right]$} & {$\left[\mathrm{Zn}(\mathrm{OH})_{2}\right]$} & {$\left[\mathrm{Zn}(\mathrm{OH})_{3}{ }^{-}\right]$} & {$\left[\mathrm{Zn}(\mathrm{OH})_{4}{ }^{2-}\right]$} & $z(\mathrm{pH})$ & $s, \mathrm{~mol} \mathrm{~L}^{-1}$ \\
\hline 9.119 & $5.781 \times 10^{-6}$ & $1.910 \times 10^{-6}$ & 0.000200 & $1.816 \times 10^{-7}$ & $7.91 \times 10^{-11}$ & $1.39 \times 10^{-7}$ & 0.000207 \\
\hline 9.120 & $5.754 \times 10^{-6}$ & $1.905 \times 10^{-6}$ & 0.000200 & $1.820 \times 10^{-7}$ & $7.94 \times 10^{-11}$ & $0.50 \times 10^{-8}$ & 0.000207 \\
\hline 9.121 & $5.728 \times 10^{-6}$ & $1.901 \times 10^{-6}$ & 0.000200 & $1.824 \times 10^{-7}$ & $7.98 \times 10^{-11}$ & $-0.38 \times 10^{-8}$ & 0.000207 \\
\hline 9.122 & $5.702 \times 10^{-6}$ & $1.897 \times 10^{-6}$ & 0.000200 & $1.828 \times 10^{-7}$ & $8.02 \times 10^{-11}$ & $-1.26 \times 10^{-7}$ & 0.000207 \\
\hline 9.123 & $5.675 \times 10^{-6}$ & $1.892 \times 10^{-6}$ & 0.000200 & $1.832 \times 10^{-7}$ & $8.05 \times 10^{-11}$ & $-2.13 \times 10^{-7}$ & 0.000207 \\
\hline
\end{tabular}

On the basis of experimental data presented in Ref. [11], $50 \mu \mathrm{g}$ Ni can be dissolved in $1 \mathrm{~L}$ water.

Table 1 Zeroing Eq. 8 for the system with $\mathrm{Zn}(\mathrm{OH})_{2}$ precipitate added to pure water 
Applying the zeroing procedure involved with charge and concentration balances and all the physicochemical data presented above, calculate:

1. the $\mathrm{pH}$ of the solution obtained at equilibrium after addition of an excess of $\mathbf{N i L}_{2}$ to pure water;

2. the solubility, $s$, of $\mathbf{N i L}_{\mathbf{2}}$ in $\mathrm{mol} \mathrm{L}^{-1}$; and

3. compare the "text-book" solubility, $s^{*}$ (Eq. 5), with the one just calculated as suggested above, and with the solubility determined experimentally in Ref. [11].

We invite our readers to participate in the Analytical Challenge by solving the puzzle above. Please send the correct solution to abc-challenge@springer.com by April 1, 2015. Make sure you enter "Solubility product challenge" in the subject line of your e-mail. The winner will be notified by e-mail and his/her name will be published on the "Analytical and Bioanalytical Chemistry" homepage at http:// www.springer.com/abc and in the journal (volume 407/issue 17) where readers will find the solution and a short explanation.
The next Analytical Challenge will be published in 407/12, May 2015. If you have enjoyed solving this Analytical Challenge you are invited to try the previous puzzles on the ABC homepage.

\section{References}

1. Clever L (2004) Chem Int 26:12-15

2. Kortly S, Sucha L (1985) Handbook of Chemical Equilibria in Analytical Chemistry. J. Wiley, New York

3. Gordus AA (1991) J Chem Educ 68:927-930

4. Michałowski T, Pietrzyk A (2006) Talanta 68:594-601

5. Michałowski T, Asuero AG (2012) J Thermodyn 2012, 723052. doi:10.1155/2012/723052

6. Beilstein F, Grosset T (1890) Z Anal Chem 29:73-78

7. Doyle JD, Parsons SA (2002) Water Res 36:3925-3940

8. Asuero AG, Michałowski T (2011) Crit Rev Anal Chem 41:151-187

9. Tschugaeff L (1905) Z Anorg Chem 46:144-169

10. Inczédy J (1976) Analytical Applications of Complex Equilibria. Horwood, Chichester

11. Claassen A, Bastings L (1959) Fresenius J Anal Chem 165:354 